\title{
PITUITARY ADENYLATE CYCLASE-ACTIVATING POLYPEPTIDE (PACAP)/VASOACTIVE INTESTINAL PEPTIDE (VIP) RECEPTOR SUBTYPES IN RAT TISSUES: INVESTIGATION OF RECEPTOR BINDING, A NOVEL VIP RECEPTOR ANTAGONIST AND CHEMICAL CROSS-LINKING
}

\author{
Masahiko Sone ${ }^{1}$, David M. Smith ${ }^{1}$, Mohammad A. Ghatei $^{1}$, Illana Gozes ${ }^{2}$, Douglas E. Brenneman ${ }^{3}$, \\ Mati Fridkin ${ }^{4}$ and Stephen R. BLoom ${ }^{1}$ \\ ${ }^{1}$ Department of Medicine, Royal Postgraduate Medical School, Hammersmith Hospital, Du Cane Road, London W12 ONN, United \\ Kingdom, ${ }^{2}$ Department of Chemical Pathology, Sackler School of Medicine, Tel Aviv University, Tel Aviv, Israel, ${ }^{3}$ Section on De- \\ velopmental and Molecular Pharmacology, Laboratory of Developmental Neurobiology, National Institute for Child Health and \\ Human Development, NIH, Bethesda, MD 20892, U.S.A., and ${ }^{4}$ Department of Organic Chemistry, Weizmann Institute of Science, \\ Rehovot, Israel
}

\begin{abstract}
Receptors for pituitary adenylate cyclase-activating polypeptide (PACAP) have been subdivided into type I receptors and II receptors. Using rat brain stem as a tissue containing type I receptors and rat lung as a tissue containing type II receptors, we investigated the binding of ${ }^{125}$ I-labelled PACAP, vasoactive intestinal peptide (VIP) and the related peptide, helodermin to these and, by chemical cross-linking, the relative molecular weight of the receptors. Type I receptors showed an $M_{\mathrm{r}}$ of 58,000 and type II an $M_{\mathrm{r}}$ of 54,000. After deglycosylation type I receptors showed an $M_{\mathrm{r}}$ of 49,000 and type II receptors an $M_{\mathrm{r}}$ of 41,000 demonstrating a high degree of glycosylation of both subtypes. This compares with the predicted (unglycosylated) $M_{\text {r }}$ 's of the recently cloned rat brain type I receptor and rat lung type II receptor of 56,000 and 49,000 , respectively. We also studied a hybrid VIP receptor antagonist (VIP-neurotensin) and showed it was unable to displace ${ }^{125} \mathrm{I}$-PACAP from type $\mathrm{I}$ receptors $\left(\mathrm{K}_{\mathrm{i}}>10 \mu \mathrm{M}\right)$ but was effective at type II receptors and propose that this peptide could be used to differentiate between PACAP effects at the two receptor subtypes.
\end{abstract}

Pituitary adenylate cyclase-activating polypeptide (PACAP) was originally isolated as a 38 amino acid peptide from sheep hypothalami in 1989 by Arimura and co-workers (19). PACAP immunoreactivity has now been demonstrated in a number of rat tissues (2) and other species, showing a remarkable degree of sequence conservation, e.g. there is only one amino acid difference between frog PACAP and the identical human/rat/ovine PACAPs (6). The biological actions of PACAP are diverse, affecting pituitary hormone release, adrenal chromaffin cell section, gastrointestinal tract function, vascular smooth muscle and spermatogenesis (for a review, see 1). Molecular cloning of the cDNA for the rat PACAP precursor protein demonstrated a 175 amino acid protein with basic amino acid processing sites either side of the 38 amino acid PACAP sequence with a carboxy-terminus glycine for amidation (22). Within the 38 amino acid sequence is a Gly-Lys-Arg sequence which specifies a cleavage site generating the 27 amino acid amidated small PACAP (PACAP 27), previously identified in ovine hypothalamus (20). The N-terminal 28 amino acids of PACAP show $68 \%$ identity with vasoactive intestinal polypeptide (VIP) indicating that PACAP is a member of the secretin/glucagon/VIP/helodermin peptide family. Indeed many of PACAP's biological actions are similar to or identical with VIP.

The receptor and effector systems utilized by 
PACAP have also been extensively examined. Using ${ }^{125}$ I-PACAP 27, specific high affinity receptors have been demonstrated in a number of tissues and species including rat central nervous system (17), rat astrocytes (34), human neuroblastoma cells (5), rat pancreatic acinar AR4-2J cells (4), bovine hypothalamus (23) and human brain (31). Interestingly, these receptors show a much higher affinity for PACAP $\left(\mathrm{IC}_{50}=\mathrm{nM}\right)$ than for VIP $\left(\mathrm{IC}_{50}=\right.$ $\mu \mathrm{M})$ despite the high degree of homology and the similar actions of the two peptides. However, PACAP binding sites have also been demonstrated in mouse splenocytes (32), rat lung (17), rat liver (26) and rat blood vessels (21) and these sites show a high and approximately equal affinity for PACAP and VIP. Shivers and colleagues have proposed that the specific PACAP sites be referred to as type I receptors and the PACAP/VIP sites as type II receptors (29). Both types of receptor mediate an increase in intracellular cAMP. ${ }^{125} \mathrm{I}$-VIP binding sites have also been subdivided into high and low affinity sites by Robberecht and colleagues by utilizing the VIP related peptide helodermin. ${ }^{125}$ I-helodermin was shown to bind only to the high affinity binding sites in rat liver membranes whereas ${ }^{125}$ I-VIP bound to both high and low affinity sites (27).

Recently, a functional cDNA clone of a VIP receptor with a predicted $M_{\mathrm{r}}$ of 48,946 was isolated from a rat lung cDNA library (15). This receptor was structurally related to the secretin receptor and its distribution was similar to that expected for a type II receptor. Interestingly, Northern analysis showed the presence of more than one mRNA in some tissues, possibly indicating different subtypes. Rat brain type I receptor cDNAs have also been characterised $(14,24)$. The predicted unglycasylated $M_{\mathrm{r}}$ of the cDNAs were 53,000 and 56,000 ( 2 clones in rat brain, 14) and 57,000 for AR4-2J cells (24). Although these results show that the type I receptors are clearly different from the type II receptors most biochemical information is available on glycosylated receptor $M_{\mathrm{r}}$ 's which cannot be directly compared.

In this paper we have further examined the binding of PACAP and VIP receptor subtypes using ${ }^{125}$ I-labelled PACAP, VIP and helodermin together with a VIP receptor hybrid antagonist (12). Here we describe the molecular identity of PACAP/VIP receptors in rat tissues and compare with the data from the cDNA clones.

\section{MATERIALS AND METHODS}

VIP was synthesized by Institute Armand Frappier
(Laval, Quebec, Canada), helodermin by Peninsula (St. Helens, U.K.) and PACAP by Peptide Products (Southampton, U.K.). The VIP receptor antagonist (hybrid VIP-neurotensin peptide) was synthesized as before (12). The sequence of the antagonist is Lys-Pro-Arg-Arg-Pro-Tyr-Thr-Asp-Asn-Tyr-ThrArg-Leu-Arg-Lys-Gln-Met-Ala-Val-Lys-Lys-TyrLeu-Asn-Ser-Ile-Leu-Asn-NH ${ }_{2}$. The VIP antagonist [4-Cl-D-Phe ${ }^{6}$, Leu $\left.{ }^{17}\right]$-VIP was supplied by Cambridge Research Biochemicals (Cambridge, U.K.), $\mathrm{Na}^{125}$ I was supplied by ICN Biomedicals (High Wycombe, Bucks, U.K.), ethylene glycol bis(succinimidyl succinate) (EGS) and Iodogen reagent were supplied by Pierce (Rockford, IL, U.S.A.). All other reagents were supplied by BDH (Poole, Dorset, U.K.) or Sigma (Poole, Dorset, U.K.).

\section{Peptide Iodination}

Peptides $(5 \mathrm{nmol})$ were iodinated by the iodogen (1,3,4,6-tetrachloro-3 $\alpha$-6 $\alpha$-diphenylglycoluril) method (8) as previously described (31), except that the reactions were carried out on ice for $5 \mathrm{~min}$.

\section{Preparation of Membranes}

Crude membranes were prepared as described previously (3). Briefly, tissues were homogenized at $4^{\circ} \mathrm{C}$ in $50 \mathrm{mM}$ HEPES pH 7.4 plus $0.25 \mathrm{M}$ sucrose with protease inhibitors using an Ultra Turrax homogenizer. The homogenates were centrifuged at $1,500 \mathrm{~g}$ for $20 \mathrm{~min}$ at $4^{\circ} \mathrm{C}$ and the supernatants then centrifuged at $100,000 \mathrm{~g}$ for $1 \mathrm{~h}$. The pellets were resuspended in buffer without sucrose and centrifuged at $100,000 \mathrm{~g}$ for $1 \mathrm{~h}$ at $4^{\circ} \mathrm{C}$. The pellets were then resuspended at $2-3 \mathrm{mg}$ protein $/ \mathrm{ml}$ (by biuret assay) aliquoted and stored at $-70^{\circ} \mathrm{C}$.

\section{Receptor Binding Assays}

Optimum binding conditions were different for the three ${ }^{125}$ I-ligands used (30). For ${ }^{125}$ I-VIP binding, $100 \mu \mathrm{g}$ of membrane protein was incubated at $30^{\circ} \mathrm{C}$ for 60 min with $0.2 \mathrm{nM}{ }^{125} \mathrm{I}-\mathrm{VIP}(500 \mathrm{~Bq})$ in $25 \mathrm{mM}$ HEPES pH 7.4, 4 mM MgCl , 2 mM EDTA, 0.25 $\mathrm{mg} / \mathrm{ml}$ bacitracin and $1 \%$ BSA. For ${ }^{125}$ I-helodermin binding, $200 \mu \mathrm{g}$ of membrane protein was incubated at $22^{\circ} \mathrm{C}$ for $90 \mathrm{~min}$ with $0.18 \mathrm{nM}{ }^{125} \mathrm{I}$-helodermin $(500 \mathrm{~Bq})$ in the same buffer as VIP binding. For ${ }^{125}$. PACAP 27 binding, $100 \mu \mathrm{g}$ of membrane protein was incubated at $30^{\circ} \mathrm{C}$ for 60 min with $0.25 \mathrm{nM}^{125} \mathrm{I}$ PACAP $27(500 \mathrm{~Bq})$ in $50 \mathrm{mM}$ HEPES $\mathrm{pH} 7.4$, $1 \mathrm{mM}$ EDTA, $0.25 \mathrm{mg} / \mathrm{ml}$ bacitracin and $3 \%$ BSA. 
Table $1 K_{d}$ and $B_{\max }$ Values of PACAP 27, VIP and Helodermin-Binding Sites from Rosenthal Plot Analysis in Rat Tissues

\begin{tabular}{|c|c|c|c|}
\hline & PACAP 27 & VIP & Helodermin \\
\hline \multicolumn{4}{|l|}{ Brain stem } \\
\hline $\mathrm{K}_{\mathrm{d}} \quad(\mathrm{nM})$ & $9.5 \pm 1.4$ & $2.8 \pm 0.3$ & $2.2 \pm 0.2$ \\
\hline $\mathrm{B}_{\max }(\mathrm{fmol} / \mathrm{mg}$ protein $)$ & $1,416 \pm 188$ & $178 \pm 37$ & $162 \pm 6.0$ \\
\hline \multicolumn{4}{|l|}{ Lung } \\
\hline $\mathrm{K}_{\mathrm{d}} \quad(\mathrm{nM})$ & $1.5 \pm \quad 0.2$ & $0.3 \pm \quad 0.03$ & $1.0 \pm 0.05$ \\
\hline $\mathrm{B}_{\max }(\mathrm{fmol} / \mathrm{mg}$ protein $)$ & $2,239 \pm 258$ & $3,694 \pm 213$ & $3,835 \pm 21$ \\
\hline \multicolumn{4}{|l|}{ Stomach fundus } \\
\hline $\mathrm{K}_{\mathrm{d}} \quad(\mathrm{nM})$ & $2.4 \pm \quad 0.2$ & $2.1 \pm \quad 0.6$ & $3.5 \pm 0.2$ \\
\hline $\mathrm{B}_{\max }(\mathrm{fmol} / \mathrm{mg}$ protein $)$ & $168 \pm 11$ & $346 \pm 22$ & $767 \pm 0.2$ \\
\hline
\end{tabular}

Results are expressed as the mean $\pm \operatorname{SEM}(n=4)$.

The final assay volume in all cases was $500 \mu 1$. Bound and free label were separated by centrifugation at $15,000 \mathrm{~g}$ for $2 \mathrm{~min}$ at $4^{\circ} \mathrm{C}$. The pellets were washed with $500 \mu \mathrm{l}$ of assay buffer at $4^{\circ} \mathrm{C}$ and counted in a $\gamma$-counter. All tubes and pipette tips were silanized to prevent binding of peptide. Nonspecific binding was determined in the presence of $0.2 \mu \mathrm{M}$ of the appropriate peptide. Specific binding was calculated as total binding minus non-specific binding. Non-specific binding was always less than $40 \%$ in the three assays in all tissues. There was no significant degradation of labelled peptides from these assays, as analysed by fast protein liquid chromatography (methods as 3 , results not shown). $\mathrm{B}_{\max }$ and $\mathrm{K}_{\mathrm{d}}$ were calculated from Rosenthal analysis of saturation equilibrium binding studies. Equilibrium displacement experiments were used to generate competition curves which were analysed by non-linear regression using Graphpad Inplot 3.0. $\mathrm{IC}_{50}$ values were converted to $\mathrm{K}_{\mathrm{i}}$ by use of the Cheng-Prusoff equation.

\section{Chemical Cross-Linking Studies}

Chemical cross-linking of receptor bound ${ }^{125} \mathrm{I}$ ligand and SDS-polyacrylamide gel electrophoresis were performed as described previously (3). Briefly, $200 \mu \mathrm{g}$ of membrane protein were incubated with $4 \mathrm{nM}{ }^{125}$ I-labelled peptide in the standard assay conditions in the presence or absence of $1 \mu \mathrm{M}$ unlabelled peptide. Membranes were pelleted $\left(15,000 \mathrm{~g}, 2 \mathrm{~min}, 4^{\circ} \mathrm{C}\right)$, washed and resuspended in $200 \mu 1$ of $50 \mathrm{mM}$ HEPES pH 7.4 with EGS in dimethyl sulphoxide added to a final concentration of $2 \mathrm{mM}$ followed by $30 \mathrm{~min}$ incubation at $22^{\circ} \mathrm{C}$. Samples were centrifuged at $15,000 \mathrm{~g}$ for $5 \mathrm{~min}$ at $4^{\circ} \mathrm{C}$ and washed twice at $4^{\circ} \mathrm{C}$ with $1 \mathrm{ml}$ of $50 \mathrm{mM}$
Tris/ $\mathrm{HCl} \mathrm{pH} \mathrm{7.4.} \mathrm{The} \mathrm{membranes} \mathrm{were} \mathrm{then} \mathrm{solu-}$ bilised in Laemmli sample buffer and run on 4\% acrylamide stacking and 10\% acrylamide resolving gels (3).

\section{Deglycosylation of Cross-Linked Receptor- Ligand Complexes}

Receptor and ${ }^{125} \mathrm{I}$-ligand were cross-linked as described above. The complex was centrifuged at $15,000 \mathrm{~g}$ for $2 \mathrm{~min}$ and the supernatant discarded. The pellet was resuspended in $80 \mu \mathrm{l}$ of buffer containing $0.25 \mathrm{M}$ sodium acetate $\mathrm{pH} 6.5,20 \mathrm{mM}$ EDTA, $1 \mathrm{mM}$ phenanthroline, $10 \mathrm{mM}$ mercaptoethanol, $6 \mathrm{mg} / \mathrm{ml}$ Nonidet P40, $1 \mathrm{mg} / \mathrm{ml} \mathrm{SDS} \mathrm{and}$ $0.5 \mu \mathrm{g} / \mathrm{ml}$ leupeptin, antipain and pepstatin and boiled for $2 \mathrm{~min}$. After cooling to room temperature, $20 \mu \mathrm{l}(100 \mathrm{mU}$, where 1 unit hydrolyses $1 \mu \mathrm{mol}$ substrate per hour at $37^{\circ} \mathrm{C}$ ) of endoglycosidase $\mathrm{F} / \mathrm{N}$ glycosidase $\mathrm{F}$ (Boehringer Mannheim Biochemica, Lewes, East Sussex, U.K.) was added and total deglycosylation performed by incubating the mixture for $18 \mathrm{~h}$ at $37^{\circ} \mathrm{C}$. Similarly treated samples, without addition of enzyme, were used as controls. Samples were then resolved on SDS polyacrylamide gels as described previously (3).

\section{RESULTS}

We initially examined the binding of ${ }^{125}$ I-labelled PACAP 27, VIP and helodermin to a number of rat tissue membranes (peripheral: liver, kidney, lung, testis, spleen, pancreas, stomach fundus, duodenum, ileum and colon. CNS: hypothalamus, hippocampus, brain stem, cerebellum and thalamus) and chose, for the reasons outlined below, to concentrate the study on brain stem, lung and stomach 
A
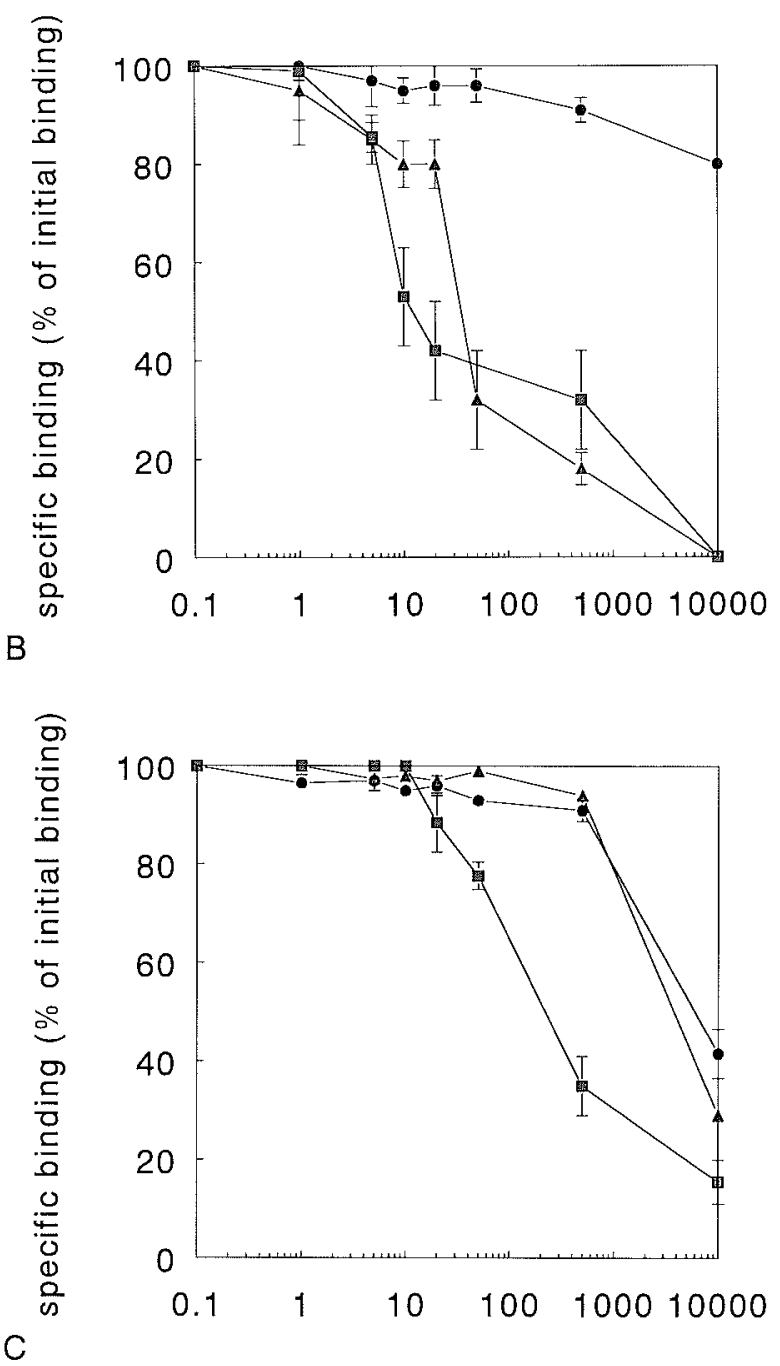

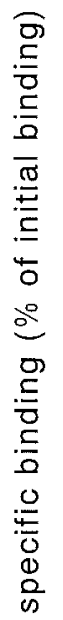

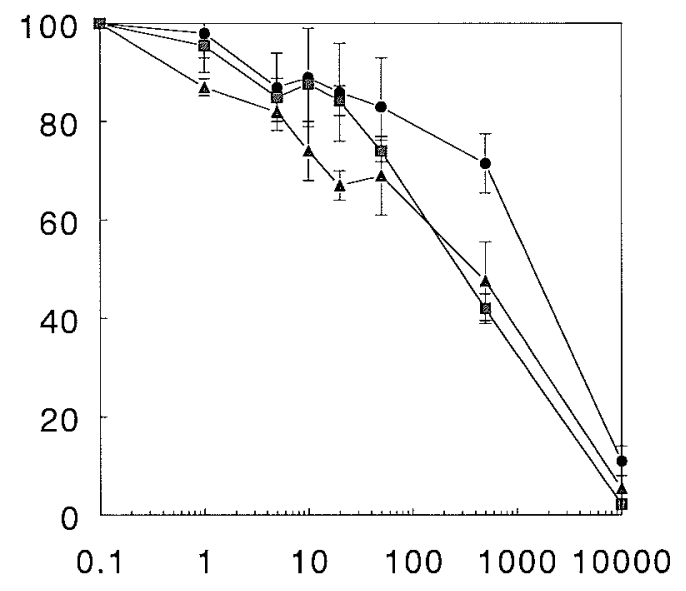

VIP hybrid antagonist ( $\mathrm{nM})$

Fig. 1 fundus. Rosenthal analysis of saturation binding data was used to quantify the number of binding sites in each of the three tissues (Table 1). Brain stem expressed almost exclusively PACAP binding sites with very few VIP binding sites. Lung membranes demonstrated high numbers of binding sites for all three radioligands, with VIP binding and helodermin binding being approximately equal and about 1.7-fold greater than PACAP 27 binding. Rosenthal analysis of VIP binding in the lung showed the presence of a single high affinity receptor $\left(\mathrm{K}_{\mathrm{d}}=0.3 \mathrm{nM}\right)$. In stomach fundus helodermin labelled twice as many sites $\left(\mathrm{K}_{\mathrm{d}}=2 \mathrm{nM}\right)$ as VIP with very low PACAP 27 binding.

We studied the effects of specific VIP receptor antagonists on displacement of radiolabelled PACAP, VIP and helodermin from membrane preparations derived from rat brain stem, lung and stomach fundus. The [4-Cl-D-Phe ${ }^{6}$, Leu $\left.{ }^{17}\right]$-VIP antagonist was virtually ineffective in all cases (results not shown). Therefore, all experiments were performed with the hybrid VIP-neurotensin antagonist, hereafter referred to as VIP hybrid antagonist. In brain stem membranes, the VIP hybrid antagonist, very poorly displaced PACAP, but was effective in displacing VIP and helodermin (Fig. 1A and Table 2). In lung membranes the VIP hybrid antagonist inhibited the binding of all three radioligands (PACAP, VIP and helodermin) being most

Fig. 1 Inhibition of ${ }^{125}$ I-PACAP $27(\bullet),{ }^{125}$ I-VIP (ム) and ${ }^{125}$ I-helodermin ( $\mathbf{E}$ ) binding by VIP antagonist in brain stem (panel A), lung (panel B) and stomach fundus (panel C) membranes. Values are expressed as percentage of maximal specific binding with mean $\pm \operatorname{SEM}(\mathrm{n}=$ 3).

Fig. 2 Autoradiograph illustrating cross-linking of ${ }^{125}$ I-PACAP 27 (lanes 1-3), ${ }^{125}$ I-helodermin (lanes 4-6) and ${ }^{125}$ I-VIP (lanes 7-9) to rat membranes. Cross-linking was performed as described in Materials and Methods, using membranes from brain stem (panel A), lung (panel B) and stomach fundus (panel C) in the absence (lanes 1, 4 and 7) and presence of $1 \mu \mathrm{M}$ PACAP 27 (lanes 2,5 and 8) or VIP (lanes 3,6 and 9). Arrowheads on the left side of the figures indicate specifically labeled proteins. The positions of molecular weights standards $\left(M_{\mathrm{r}} \times 10^{-3}\right)$ are shown on the right side of the figures. Protein standards are: phosphorylase $b, 97,400$; albumin, 66,000; ovalbumin, 45,000; and carbonic anhydrase, 29,000 . df, dye front. Each autoradiograph is representative of at least 3 separate experiments. 
A

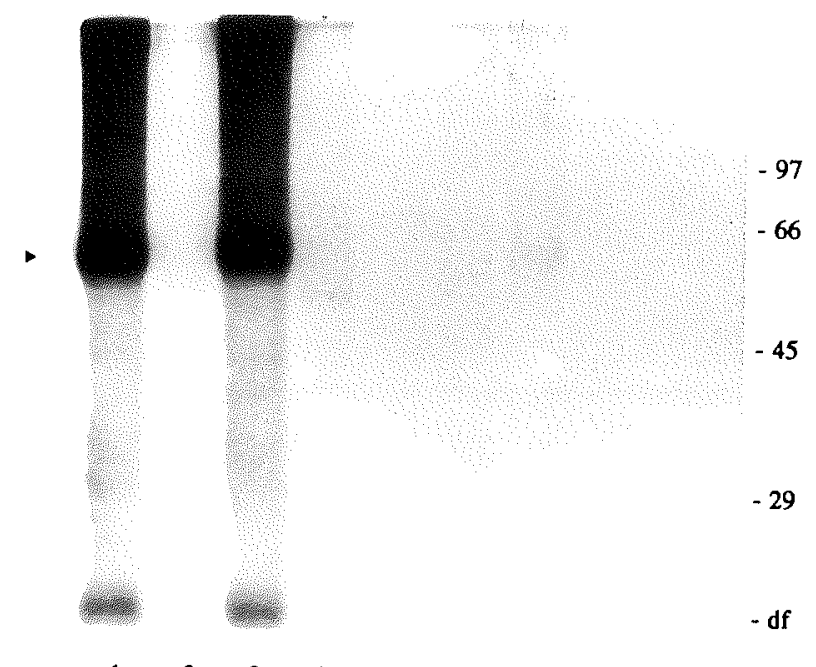

B

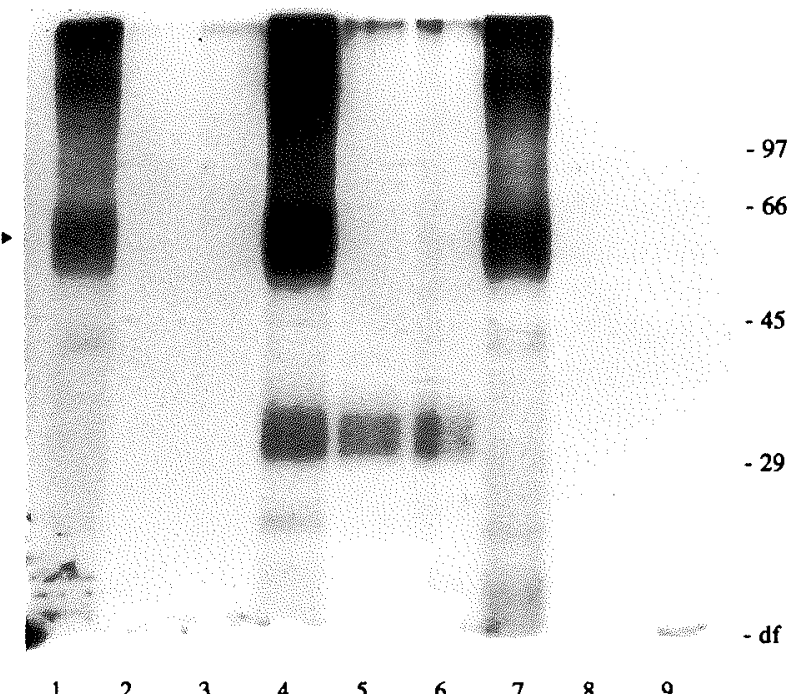

C

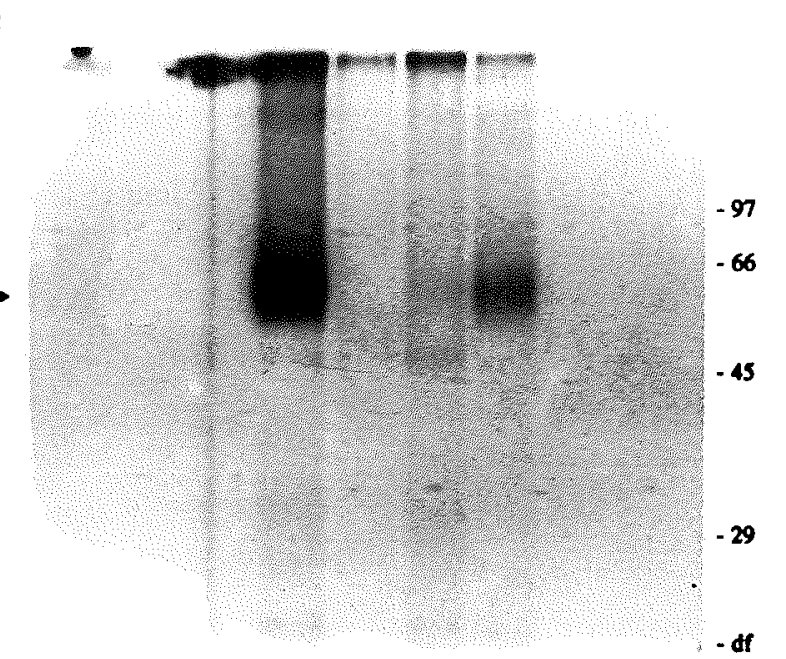

$\begin{array}{lllllllll}1 & 2 & 3 & 4 & 5 & 6 & 7 & 8 & 9\end{array}$

Fig. 2 
Table 2 Effects of VIP Antagonist on ${ }^{125}$ I-PACAP, -VIP and -Helodermin Binding in Rat Membranes

\begin{tabular}{lccc}
\hline & \multicolumn{3}{c}{$\mathrm{K}_{\mathrm{i}}(\mathrm{nM})$} \\
\cline { 2 - 4 } & PACAP 27 & \multicolumn{1}{c}{ VIP } & Helodermin \\
\hline Brain stem & $>10 \mu \mathrm{M}$ & $44 \pm 11$ & $15 \pm 3.0$ \\
Lung & $5,583 \pm 1,523$ & $2,274 \pm 151$ & $209 \pm 38$ \\
Stomach fundus & $1,395 \pm 332$ & $169 \pm 23$ & $282 \pm 50$ \\
\hline
\end{tabular}

Results are expressed as the mean $\pm \operatorname{SEl} \mathrm{I}_{\mathrm{I}}(\mathrm{n}=3)$.

potent in helodermin displacement $\left(\mathrm{K}_{\mathrm{i}}=200 \mathrm{nM}\right)$ and least effective at VIP and PACAP displacement $\left(\mathrm{K}_{\mathrm{i}}=2 \mu \mathrm{M}\right.$ and $6 \mu \mathrm{M}$ respectively) (Fig. $1 \mathrm{~B}$ and Table 2). The VIP hybrid antagonist was also effective in displacing helodermin and VIP from stomach fundus $\left(\mathrm{K}_{\mathrm{i}}=200 \mathrm{nM}\right)$, while PACAP required 10 -fold higher concentrations (Fig. 1C and Table 2).

The technique of chemical cross-linking was used to determine the molecular identity of the receptor sites in the three tissues. In brain stem (Fig. 2A) only ${ }^{125}$ I-PACAP binding showed any cross-linking because of the low numbers of VIP and helodermin binding sites. PACAP cross-linking was inhibited by addition of $1 \mu \mathrm{M}$ PACAP but not VIP. The major labelled band demonstrated an $M_{\mathrm{r}}$ of 61,000 giving the $M_{\mathrm{r}}$ of the receptor as 58,000 after subtracting the mass of the cross-linked ligand. In lung membranes (Fig. 2B) all three labels cross-linked to a band of $M_{\mathrm{r}} 57,000$ giving an $M_{\mathrm{r}}$ of 54,000 for the receptor. Labelling of this band was inhibited by incubation with $1 \mu \mathrm{M}$ unlabelled PACAP or VIP. ${ }^{125}$ I-helodermin also labelled a band $M_{\mathrm{r}} 31,000$ which was not completely removed by unlabelled PACAP or VIP and may represent non-specific binding. Stomach fundus membranes showed cross-linking of labelled VIP and helodermin to a band of $M_{\mathrm{r}} 59,000$ giving an $M_{\mathrm{r}}$ of 55,000 for the receptor (Fig. 2C). No labelling with PACAP was observed because of the low number of binding sites in this tissue. To check whether the differences in $M_{\mathrm{r}}$ of the three receptors was not due to variation in gel running, receptors from the three tissues were cross-linked and resolved on the same gel. The original observations of $M_{\mathrm{r}}$ were verified (Fig. 3). To determine the $M_{\mathrm{r}}$ of the unglycosylated forms of the brain stem and lung receptors we treated cross-linked receptors from brain stem and lung with an endoglycosidase F/N glycosidase $\mathrm{F}$ enzyme mixture. Enzyme treatment reduced the $M_{\mathrm{r}}$ of ${ }^{125} \mathrm{I}$-VIP cross-linked lung recep-

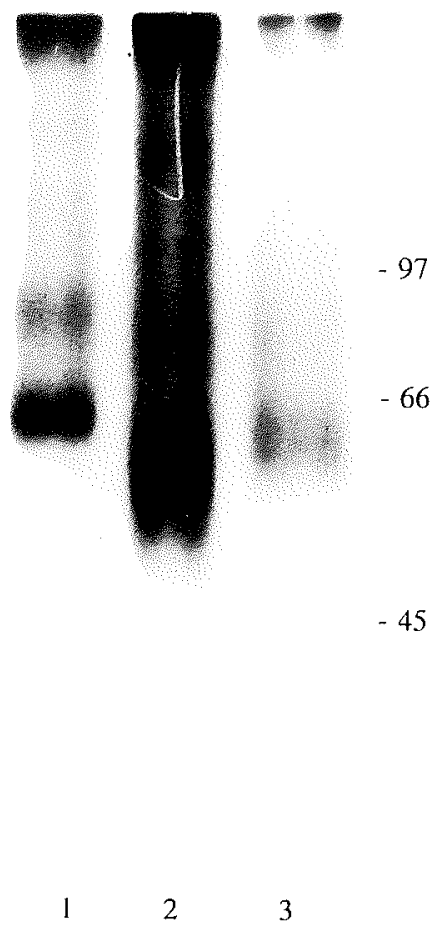

Fig. 3 Chemical cross-linking of ${ }^{125}$ I-PACAP 27 to rat brain stem (lane 1), ${ }^{125}$ I-VIP to rat lung (lane 2) and ${ }^{125}$ Ihelodermin to rat stomach fundus (lane 3 ) in the absence of unlabeled peptide. The positions of molecular weight standards $\left(M_{\mathrm{r}} \times 10^{-3}\right)$ are shown on the right side of the figure. The autoradiograph is representative of 4 separate experiments.

tors from 57,000 to 44,000 and the $M_{\mathrm{r}}$ of ${ }^{125} \mathrm{I}-$ PACAP 27 cross-linked brain stem receptors from 61,000 to 52,000 (Fig. 4).

\section{DISCUSSION}

We have examined binding of PACAP 27, VIP and helodermin to membranes from rat brain stem, lung and stomach fundus. Brain stem showed high 


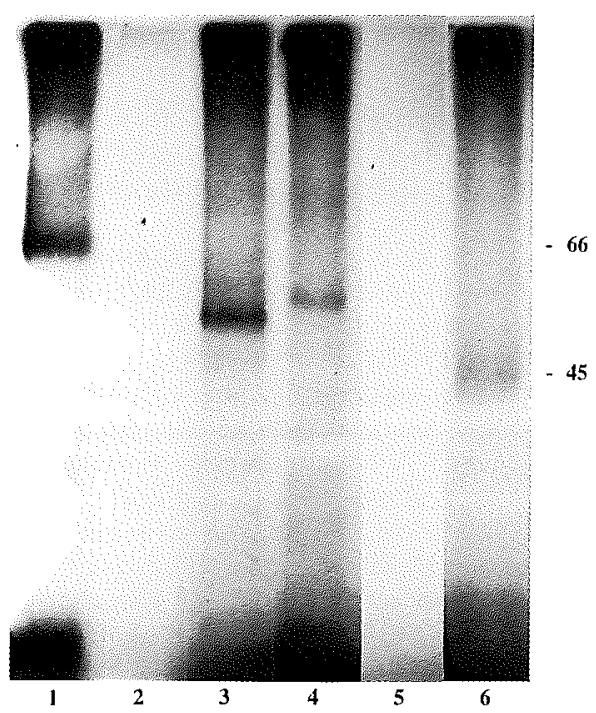

Fig. 4 Effects of deglycosylation on cross-linked ${ }^{125}$ IPACAP 27-receptor complexes from rat brain stem (lanes 1-3) and ${ }^{125}$ I-VIP-receptor complexes from rat lung (lanes 4-6) in the absence (lanes 1 and 4) and presence of $1 \mu \mathrm{M}$ PACAP 27 (lane 2) or VIP (lane 5) and with endoglycosidase $\mathrm{F} / \mathrm{N}$ glycosidase $\mathrm{F}$ enzyme treatment (lanes 3 and 6). Deglycosylation was performed as described in Materials and Methods. The positions of molecular weight standards $\left(M_{\mathrm{r}} \times 10^{-3}\right)$ are shown on the right side of the figure. The autoradiograph is representative of 3 separate experiments.

numbers of PACAP binding sites but very few VIP binding sites. We $(17)$ and others $(18,28)$ have shown that PACAP binding sites in the rat brain are almost exclusively type I, i.e. not displaced by VIP. However VIP binding was present in brain stem indicating some type II receptors. In contrast to this, large amounts of VIP and PACAP binding were identified in the lung and these are typical type II receptors $(17,29)$. VIP binding in the lung was a single type of high affinity $\left(\mathrm{K}_{\mathrm{d}}=0.3 \mathrm{nM}\right)$ similar to that described in rat liver $\left(\mathrm{K}_{\mathrm{d}}=0.8 \mathrm{nM}\right)$ as high affinity 'helodermin labelled' sites (27). No low affinity sites $\left(\mathrm{K}_{\mathrm{d}}=9 \mathrm{nM}\right)(27)$ were detected in rat lung and therefore all sites were labelled by helodermin (Table 1). Low affinity VIP binding sites may be present in lung, but since our results were calculated from Rosenthal plots of saturation data where the maximum concentration of labelled peptide was $4 \mathrm{nM}$ the detection of these sites may be problematical. In stomach fundus helodermin labelled twice as many sites $\left(\mathrm{K}_{\mathrm{d}}=3 \mathrm{nM}\right)$ as VIP, suggesting that in this tissue helodermin labels sites other than high affinity VIP sites. The nature of these sites remains to be determined pharmacologically. Thus, we chose brain stem membranes as a model for type I receptors, lung for type II and stomach fundus as a tissue showing 'helodermin' binding but very little PACAP binding.

The VIP hybrid antagonist was ineffective at displacing type I receptors (labelled by PACAP) in brain stem but did displace the small number of type II receptor (labelled by VIP) present in this tissue. The VIP displacement curve was very similar to the curve obtained with cortical astrocytes (11). Indeed, here we obtained a $\mathrm{K}_{\mathrm{i}}$ of $44 \pm 11 \mathrm{nM}$ (Table 2), while in cortical astroyctes we have obtained a $\mathrm{K}_{\mathrm{i}}$ of $74 \mathrm{nM}(11)$. In the astrocytes, this receptor was shown to be associated with VIP-stimulated cAMP formation $\left(\mathrm{EC}_{50}=59 \mathrm{nM}\right)$. The inability of the VIP hybrid antagonist, like VIP itself, to displace type I receptors in brain stem was also demonstrated in thalamic and cortical membranes which also express mainly type I receptors (results not shown). However, in lung membranes, the VIP hybrid antagonist inhibited the binding of all three peptides in a similar manner to results obtained in lymphoid cells, with VIP (13). Taken together, these results indicate that the VIP hybrid antagonist may be useful in distinguishing PACAP effects at type I (PACAP specific, antagonist inactive) and type II receptors (VIP effects or PACAP effects via these receptors, antagonist effective) which is not possible at present. Moreover, the hybrid VIP antagonist may recognise VIP/helodermin specific receptors, not recognised by PACAP.

Chemical cross-linking of ${ }^{125}$ I-PACAP 27 to brain stem membranes gave an $M_{\mathrm{r}}$ of 58,000 for this receptor and as expected for a type I receptor the labelling of this band was not inhibited by VIP. The $M_{\mathrm{r}}$ agrees well with the reported $M_{\mathrm{r}}$ for rat hypothalamic $(57,000)(9)$, rat astrocyte $(57,000)(33)$ and bovine brain $(57,000)(23)$ type I PACAP receptors. In lung membranes cross-linking experiments demonstrated a band of $M_{\mathrm{r}} 54,000$ and as expected for a type II PACAP/VIP receptor labelling of the band was completely inhibited by unlabelled PACAP or VIP. The $M_{\mathrm{r}}$ of 54,000 agrees well with previous data on rat lung VIP receptors, i.e. $M_{\mathrm{r}}$ 54,000 (16), 53,000 (7) and 55,000 (25). The molecular weight of the cloned rat lung VIP receptor was predicted to be 49,000 (15). This size would not take account of glycosylation. The deglycosylated form reported in this paper has an $M_{\mathrm{r}}$ of 41,000 . Similarly cDNAs for type I PACAP receptors were assigned unglycosylated $M_{\mathrm{r}}$ 's of 53,200 and 56,400 in rat brain (14) and 57,000 in AR4-2J cells (24). 
Here we report an $M_{\mathrm{r}}$ of 49,000 for the deglycosylated rat brain stem receptor which may correspond to either of the cDNA clones. In their paper on AR4-2J cells Pisegna and Wank (24) claim that the predicted $M_{\mathrm{r}}$ of 57,000 compares well to cross-linking experiments showing $M_{\mathrm{r}}$ 's of 57,000 in rat hypothalamus (9) and bovine brain (23). However, this would assume that the cross-linked receptors showed no glycosylation which is clearly not the case. In fact, though not commented on, the crosslinked glycosylated AR4-2J receptor shows on $M_{\mathrm{r}}$ of 65,000. ${ }^{125}$ I-helodermin labelled an $M_{\mathrm{r}} 55,000$ band which differs from the only reported helodermin preferring VIP receptor in human SUP-T1 lymphoblasts $\left(M_{\mathrm{r}}=63,000\right)(10)$. No similar receptors have yet been characterised in rat tissues. Thus deglycosylation of the type I and type II receptors revealed that both receptors were highly glycosylated and that a direct comparison with the predicted $M_{\mathrm{r}}$ 's from molecular cloning showed differences, possibly due to anomalous running of the receptors on SDS-PAGE.

We thank the Hammersmith and Acton Special Trustees and Hammersmith and Queen Charlotte's Special Health Research Committee for support.

Received 20 April 1994; and accepted 28 April 1994

\section{REFERENCES}

1. Arimura A. (1992) Pituitary adenylate cyclase activating polypeptide (PACAP): discovery and current status of research. Regul. Pept. 37, 287-303

2. Arimura A., Somogyvári-Vigh A., Mryata A., Mizuno K., CoY D. H. and KITADA C. (1991) Tissue distribution of PACAP as determined by RIA: highly abundant in the rat brain and testes. Endocrinology 129, 2787-2789

3. Bhogal R., Smith D. M. and Bloom S. R. (1992) Investigation and characterisation of binding sites for islet amyloid polypeptide in rat membranes, Endocrinology 130, 906-913

4. Buscail L., Gourlet P., Cauvin A., De Neef P., Gossen D., Arimura A., Miyata A., Coy D. H., Robberecht P. and Christophe J. (1990) Presence of highly selective receptors for PACAP (pituitary adenylate cyclase activating polypeptide) in membranes from the rat pancreatic acjnar cell line AR4-2J. FEBS Lett. 262, 77-81

5. Cauvin A., Buscail L., Gourlet P., De Neef P., Gossen D., Arimura A., Miyata A., Coy D. H., Robberechr P. and CHRISTOPHE J. (1990) The novel VIP-like hypothalamic polypeptide PACAP interacts with high affinity receptors in the human neuroblastoma cell line NB-OK. Peptides 11, 773-777

6. Chartrel N., Tonon M.-C., Vaudry H. and Conlon J. M. (1991) Primary structure of frog pituitary adenylate cyclase activating peptide (PACAP) and effects of ovine PACAP on frog pituitary. Endocrinology 129, 3367-3371

7. Dickinson K. E. J., Schachter M., Miles C. M. M., Coy
D. H. and Sever P. S. (1986) Characterisation of vasoactive intestinal peptide (VIP) receptors in mammalian lung. Peptides 7, 791-800

8. Fracker P. J. and SPECK J. C. (1978) Protein and cell membrane iodinations with a sparingly soluble chloroamide, 1,3,4,6,tetrachloro- $3 \alpha, 6 \alpha$, diphenylglycoluril. Biochem. Biophys. Res. Commun. 80, 849

9. Gottschall P. E., Tatsuno I. and Arimura A. (1991) Hypothalamic binding sites for pituitary adenylate cyclase activating polypeptide: characterisation and molecular identification. FASEB J. 5, 194-199

10. Gourlet P., Robberecht P. and Christophe J. (1991) Molecular characterisation of helodermin preferring VIP receptors in SUP-T1 lymphoma cells: evidence for receptor glycosylation. J. Recep. Res. 11, 831-848

11. Gozes I., McCune S. K., Jacobson L., Warren D., Moody T. W., Fridkin M. and Brenneman D. E. (1991) An antagonist to vasoactive intestinal peptide affects cellular functions in the central nervous system. J. Pharmacol. Exp. Ther: 257, 959-966

12. Gozes I., Meltzer E., Rubinrout S., Brenneman D. E. and FRIDKIN M. (1989) Vasoactive intestinal peptide potentiates sexual behavior: inhibition by novel antagonist. Endocrinology 125, 2945-2949

13. Gozes Y., Brenneman D. E., Fridkin M., Asofsky R. and Gozes I. (1991) A VIP antagonist distinguishes VIP receptors on spinal cord cells and lymphocytes. Brain Res. 540, 319-321

14. Hosoya M., Onda H., Ogi K., Masuda Y., Miyamoto Y., Ohtaki T., Okazaki H., Arimura A, and Fujino M. (1993) Molecular cloning and functional expression of rat cDNA's encoding the receptor for pituitary adenylate cyclase activating polypeptide (PACAP). Biochem. Biophys. Res. Commun. 194, 133-143

15. Ishihara T., Shigemoto R., Mori K., Takahashi K. and Nagata S. (1992) Functional expression and tissue distribution of a novel receptor for vasoactive intestinal polypeptide. Neuron 8, 811-819

16. Kermode J. C., Deluca A. W., Zilberman A., Valliere J. and SHreEve S. M. (1992) Evidence for the formation of a functional complex between vasoactive intestinal peptide, its receptor and $\mathrm{G}_{\mathrm{s}}$ in lung membranes. J. Biol. Chem. 267, 3382-3388

17. Lam H. C., Takahashi K., Ghatei M. A., Kanse S. M., POLAK J. M. and BLOOM S. R. (1990) Binding sites of a novel neuropeptide pituitary adenylate cyclase activating polypeptide in the rat brain and lung. Eur. J. Biochem. 193, 725729

18. Masuo Y., Ohtakı T., Masuda Y., Tsuda M. and Fujino M. (1992) Binding sites for pituitary adenylate cyclase activating polypeptide (PACAP): comparison with vasoactive intestinal peptide (VIP) binding site localization in rat brain sections. Brain Res. 575, 113-123

19. Miyata A., Arimura A., Dahl R. R., Minamino N., Uehara A., Jiang L., Culler M. D. and Coy D. H. (1989) Isolation of a novel 38 residue-hypothalamic polypeptide which stimulates adenylate cyclase in pituitary cells. Biochem. Biophys. Res. Commun. 164, 567-574

20. Miyata A., Jiang L., Dahl R. D., Kitada C., Kubo K., Fujino M., Minamino N. and ARimura A. (1990) Isolation of a neuropeptide corresponding to the $\mathrm{N}$-terminal 27 residues of the pituitary adenylate cyclase activating polypeptide with 38 residues (PACAP 38). Biochem. Biophys. Res. Commun. 170, 643-648 
21. Nandita K. A., Benito-Orfila M. A., Smith D. M., GhaTEI M. A. and BLOOM S. R. (1991) Action of pituitary adenylate cyclase activating polypeptide and vasoactive intestinal polypeptide on the rat vascular system: effects on blood pressure and receptor binding. J. Endocrinol. 129, 69-73

22. Ogi K., Kimura C., Onda H., Arimura A. and Fujino M. (1990) Molecular cloning and characterisation of cDNA for the precursor of rat pituitary adenylate cyclase activating polypeptide (PACAP). Biochem. Biophys. Res. Commun. 173, 1271-1279

23. Ohtaki T., Watanabe T., Ishibashi Y., Kitada C., Tsuda M., Gottschall P. E., Arimura A. and Fujino M. (1990) Molecular identification of receptor for pituitary adenylate cyclase activating polypeptide (PACAP) in bovine brain membrane fraction. Biochem. Biophys. Res. Commun. 171, 838-844

24. Pisegna J. R. and WANK S. A. (1993) Molecular cloning and functional expression of the pituitary adenylate cyclase-activating polypeptide type I receptor. Proc. Nat. Acad. Sci. USA 90, 6345-6349

25. Provow S. and Veliçelebi G, (1987) Characterisation and solubilisation of vasoactive intestinal peptide receptors from rat lung membranes. Endocrinology 120, 2442-2452

26. Robberecht P., Gourlet P., Cauvin A., Buscail L., DeNeef P., Arimura A. and Christophe J. (1991) PACAP and VIP receptors in rat liver membranes. Amer. J. Physiol. 260, G97-G102

27. Robberecht P., Waelbroeck M., DeNeef P., Camus J.-C., Vandermeers A., Vandermeers-Pieret M.-C. and ChrisTOPHE J. (1984) Specific labelling by [ ${ }^{125}$ I] helodermin of high affinity VIP receptors in rat liver membranes. FEBS Lett. 172, 55-58
28. Schäfer H., Schwarzhoff R., Creutzfeld W. and Schmid W. E. (1991) Characterisation of a guaninenucleotide-binding-protein coupled receptor for pituitary adenylate-cyclase activating polypeptide on plasma membranes from rat brain. Eur. J. Biochem. 202, 951-958

29. Shivers B. D., Gorcs T. J., Gottschall P. E. and Arimura A. (1991) Two high affinity binding sites for pituitary adenylate cyclase activating polypeptide have different tissue distributions. Endocrinology 128, 3055-3065

30. Suda K., Smith D. M., Ghatei M. A. and Bloom S. R. (1992) Investigation of the interaction of VIP binding sites with VIP and PACAP in human brain. Neurosci. Lett. 137, $19-23$

31. Suda K., Smith D. M., Ghatei M. A., Murphy J. K. and BLOOM S. R. (1991) Investigation and characterisation of receptors for pituitary adenylate cyclase activating polypeptide in human brain by radioligand binding and chemical cross-linking. J. Clin. Endocrinol. Metab. 72, 958-964

32. Tatsuno I, Gottschall P. E. and Arimura A. (1991) Inhibition of mitogen-stimulated proliferation of murine splenocytes by a novel neuropeptide, pituitary adenylate cyclase activating polypeptide: a comparitive study with vasoactive intestinal peptide. Endocrinology 128, 728-734

33. Tatsuno I., Gottschall P. E. and Arimura A. (1991) Specific binding sites for pituitary adenylate cyclase activating polypeptide (PACAP) in rat cultured astrocytes: molecular identification and interaction with vasoactive intestinal peptide (VIP). Peptides 12, 617-621

34. Tatsuno I., Gottschall P. E., Köves K. and Arimura A. (1990) Demonstration of specific binding sites for pituitary adenylate cyclase activating polypeptide (PACAP) in rat astrocytes. Biochem. Biophys. Res. Commun. 168, 1027-1033 